\title{
Vətəndaş elminin informasiya təhlükəsizliyi haqqında
}

\author{
Təhmasib Fətəliyev ${ }^{1}$, Nərgiz Verdiyeva ${ }^{2}$ \\ ${ }^{1,2}$ AMEA İnformasiya Texnologiyaları İnstitutu, Bakı, Azərbaycan
}

depart3eit.science.az

\begin{abstract}
Xülasə-Çoxlu sayda könüllünün geniş məkan və zaman kateqoriyalı kəmiyyət ölçmələri və müşahidələrdə iştirakı ilə xarakterizə olunan vətəndaş elmi informasiya texnologiyalarının tətbiqi ilə sürətlə inkişaf edir. Məqalə onun səmərəli fəaliyyətini təmin etmək məqsədi ilə informasiya təhlükəsizliyi məsələlərinin tədqiqinə həsr olunmuşdur. İnformasiya təhlükəsizliyinin konfidensiallıq, tamlıq, əlyetənlik vo fordi molumatların qorunması kimi məsələləri araşdırılmış, vətəndaş elminin effektiv mühafizəsi üçün prioritet istiqamətlər göstərilmişdir.
\end{abstract}

Açar sözlor-e-elm; votondaş elmi; açıq elm; informasiya tohlükasizliyi; votondaş elmi layiholori.

\section{GïİS}

İnformasiya texnologiyalarının (IT) geniş tətbiqi nəticəsində informasiyanın toplanması, saxlanılması, emalı və paylanması məslələrini son dərəcədə inkişaf etdirmiş və insan fəaliyyətinin bütün sahələrini, xüsusən də elmi-tədqiqatları dəyişmişdir. $\mathrm{Bu}$ naliyyətlərin əldə olunmasında nəzəriyyə və praktika ilə yanaşı elm üçün üçüncü bir əsas alətə çevrilmiş və onun həyata keçiriməsinin yeni yollarını yaratmış e-elm mühüm rol oynayır [1]. Onun inkişafi nəticəsində yeni bir istiqamət olaraq vətəndaş elmi (VE) formalaşır, eyni zamanda elmi fəaliyyətdə açıqlıq və şəffaflıq prinsiplərini ifadə edən "Açıq elm" konsepsiyası da getdikcə reallaşır. İT-nin sürətli inkişafi və geniş tətbiqi ilə əldə olunmuş bu yeniliklərin səmərəli fəaliyyətinin təşkilində informasiya təhlükəsizliyinin təmin edilməsi mühüm əhəmiyyətə malikdir.

Təqdim edilən işdə VE-nin formalaşması və inkişafında informasiya təhlükəsizliyi problemləri araşdırılmış və onların həllinin konseptual məsələləri işlənmişdir.

\section{VӘTəNDAȘ ELMINDӘ TəHLÜKəSIZLIYIN MÖVCUD VəZIYYӘTİ}

E-elmin inkişafının yeni bir istiqaməti kimi formalaşan VEni xarakterizə edən cəhətlər geniş məkan və zaman kateqoriyalı kəmiyyət ölçmələri və müşahidələr, böyük həcmli verilənlərin toplanması, məlumatların toplanmasında açıq təbii şəraitdə çoxlu sayda könüllünün iştirakı, maliyyələşmənin olmaması, verilənlərin onlayn toplanması, tədqiqatların aparılmasına dəstək üçün yaxşı işlənmiş mexanizmlərin, yardımçı materialların və professional köməyin təqdim olunması və s.dir. VE sahəsində layihələrin yüz ildən artıq fəaliyyət göstərməsinə baxmayaraq, son zamanlar onların sayı kəskin artmağa başlamışdır. Bu inkişaf VE-nin həyata keçirilməsində müasir texniki və proqram vasitələrinin təyinatlı tətbiqi ilə izah olunur [2]. Müasir IT elmi tədqiqatlarda verilənlərin toplanmasının miqyasının artmasında, informasiyanın çatdırılmasında, ideyaların ötürülməsində, iştirakçıların prosesə cəlb edilməsi üsullarında, verilənlərin emalında, vizuallaşdırmada interaktiv iştirak üçün geniş imkanlar spektri yaratmışdır. Xüsusən də mobil İnternetin və sensorların istifadəsi ilə verilənlərin kütləvi toplanması imkanını təmin edir. Bundan başqa, texnoloji nailiyyətlər vətəndaş elmi haqqında verilənləri daha əlçatan edir və vətəndaş alimlərə verilənlərin toplanmasından əlavə imkanlar verərək verilənlərin vizuallaşması və təhlili üçün alətlər təklif edir. Beləliklə, bütün bu texnoloji vasitələrin tətbiqi VE-nin inkişafında mühüm rol oynayır. Daha geniş auditoriyanı əhatə edərək, VE geniş ictimaiyyətə yeni biliklər əldə etməyin asan yolunu təqdim edir. Lakin hər bir sahədə olduğu kimi, VE-də də iştirakçılar üçün bir sıra təhlükə və təhdidlər mövcud ola bilər.

Vətəndaş alim və praktiklərin qlobal cəmiyyətini formalaşdırmaq məqsədi ilə müxtəlif beynəlxalq təşkilatlar vardır. Onlar fəaliyyətləri ilə VE-nin inkişafına kommunikasiya, koordinasiya və təhsil vasitəsi ilə dəstək verir. Məsələn, Avropa Vətəndaş Elmi Assosiasiyasının (AVEA) məqsədi VE-nin inkişafını, xüsusilə, Avropa Birliyi ərazisində ətraf mühitin monitorinqində tətbiqini görmokdir [3]. AVEA VE-də informasiya təhlükəsizliyi məsələlərinin həllində maraqlıdır. Onun təşəbbüsü ilə bəyan edilmiş "VE-nin 10 prinsipi"nin 7 və $10-\mathrm{cu}$ bəndində təhlükəsizlə əlaqəli məqamlara toxunulmuşdur:

- Mümkün və uyğun olduqda, VE layihələrinin verilənləri və meta-verilənləri ictimaiyyətə açıqdır və nəticələr açıq əlyetənlik formatında nəşr olunur. Verilənlərin paylaşılması, əgər təhlükəsizlik və gizlilik problemləri yoxdursa, layihə zamanı və ya ondan sonra həyata keçirilə bilər.

- VE layihələrinin liderləri müəllif hüququ, intellektual mülkiyyət, informasiya mübadiləsi haqqında razılıq (müqavilə), konfidensiallıq, məsuliyyət, ətraf mühitə təsir ilə əlaqədar hüquqi və etik aspektləri nəzərə alır.

VE onlayn mühitlər vasitəsi ilə elmdə vətəndaşların iştirakı və qarşılıqlı elmi əməkdaşlığı nəticəsində formalaşır. VE təşəbbüslərinin sayında sürətli artımla yanaşı onun əhatə dairəsinin genişlənməsi də müşahidə olunur. Məsələn, təkcə "Birgə edə biləcəyimiz elm" şüarını əsas götürmüş SciStarter təşkilatının (https://scistarter.com) verilənlər bazasında 1600dən çox vətəndaş elmi layihəsi və $100 \quad 000$ həvəskar qeydiyyatdan keçmişdir. 


\section{“Informasiya tohlükosizliyinin aktual multidissiplinar elmi-praktiki problemlori” IV respublika konfransl, 14 dekabr 2018-ci il}

Hər gün milyonlarla vətəndaş alim dünyanın hazırkı hədəflərini dəstəkləmək üçün müxtəlif tədqiqatlarda iştirak edir [4]. eBird könüllüləri təbiətdə quşların müşahidələrinə töhfə verirlər ki, bu da torpağın mühafizəsi siyasətindən xəbər verən bir amil olaraq çıxış edir (http://ebird.org). FoldIt iştirakçıları HIV-in reproduksiyası üçün mühüm olan proteini müəyyən etməyə kömək edirlər (http://fold.it).

Dünyada VE layihələrinin sayının artım dinamikası olduqca böyükdür, bu fakt CitSci.org portalın timsalında öz təsdiqini tapır. Hazırda sayta qoşulan könüllü koordinatorlar yaratdıqları 693 layihə üzrə lokal, regional və/və ya qlobal problemlərin həlli üçün ümumilikdə 936102 ölçmə (analiz üçün verilənlər) təqdim ediblər.

Beləliklə, çoxlu sayda könüllünün geniş məkan və zaman kateqoriyalı kəmiyyət ölçmələri və müşahidələrdə iştirakı ilə xarakterizə olunan VE-də təhlükəsizlik problemlərinin həlli mürəkkəb və aktual məsələ kimi təsdiqini tapır.

Məlumdur ki, fərdi iştirakçıların gizliliyi və təhlükəsizliyini təmin etmək üçün ənənəvi elmi-tədqiqat fəaliyyətinin təşkilində məlumatlı razılıq kimi yaxşı düşünülmüş qaydalardan istifadə olunur. Buna əks olaraq, VE layihələri cəmiyyət üzvləri tərəfindən yaradılır və onlar misal olaraq, havanın çirklənməsi, yaşayış mühitinin itirilməsi kimi ümumi problemlər üzrə birləşirlər. Bu layihələr ictimaiyyətin üzvləri tərəfindən əldə edilmiş verilənlərdən istifadə edir. Bunun nəticəsi olaraq, VE təcrübələrini və onları dəstəkləyən texnologiyalar layihələndirilərkən gizlilik nəzərə alınmamış ola bilər. Lakin bu hallarda, elmi-tədqiqat üçün olduğu kimi, iştirakçı gizliliyinin qorunması mühüm problem olmalıdır.

Vətəndaşların iştirak etdiyi onlayn VE layihəsində iştirakçılar qeydiyyatdan keçməklə apardığı müşahidələrin nəticələrini layihənin veb-saytında yerləşdirirlər. Bu layihələrin böyük bir qismi təbiət və ətraf mühitlə bağlı olduğundan müşahidə nəticələri çəkilmiş şəkillər, videolar olacaq. Layihənin veb-saytında isə açıq əlyetənlik siyasəti qüvvədədir, ona görə də bütün verilənlər hamıya açıqdır. Bu layihələr iştirakçılar haqqında şəxsi informasiyanın veb-saytda hamıya açıq ola bilməsindən narahatdır. Bundan əlavə, yüklənilmiş şəkillərdə üzdən tanına bilən insanlar və onların harada, kimlə olduqları təsvir oluna bilər. Bu cür, xüsusilə də uşaqlar təsvir olunan şəkillər müvafiq icazə olmadan paylaşıldıqda layihə problem yaşaya bilər.

Şəkillərin çəkildiyi yer açıq paylaşıldığından iştirakçıların evləri, məktəbləri, iş yerlərinin yerləşdiyi əraziləri tanına bilinməsini təhlükəsizlik baxımından nəzərə alınmalıdır. Bu, pis niyyətlilərin həmin iştirakçıları tapa bilməsi, onların mənsubiyyətləri barədə şəxsi məlumatları aşkarlaması təhlükəsini yaradır. Layihə tədris məqsədli olarsa, o həm də az yaşlı uşaqların məsuliyyətli şəxs tərəfindən nəzarətdə olmasını təmin etməlidir.

Göstərdiyimiz nümunə ilə bağlı təhlükəsizlik problemləri şəxsi informasiyanın konfidensiallığı, təqib və təcavüz, fərdi məxfiliyin qorunması ilə əlaqədar vətəndaş azadlıqları realdır. Təhlükəsizliyi "könüllü olaraq göndərilmiş şəxsi məlumatlara giriş imkanı hüququ" kimi təyin etmək olar. Şəxsi məlumatlar dedikdə şəxsiyyəti müəyyənləşdirən məlumatlar (personally identifiable information, PII) nəzərdə tutulur. Office of Management and Budget tərəfindən müəyyən olunmuşdur ki,
PII-ə fərdi identifikasiya edə bilən informasiya (ad və soyad kimi) və fərdlə əlaqəli informasiya (tibbi məlumatlar və ya IP ünvan) daxildir. Həmçinin könüllülərin müraciətlərində qeyd olunmuş şəxsi məlumatlar hesab olunur. Məsələn, coğrafi məkanın qeyd olunduğu müşahidələr tədqiq olunan nümunələrin və eyni zamanda onu qeydə alan könüllünün yerləşdiyi məkanı aşkar edir:

- VE layihələri könüllüləri potensial təhlükə və təhlükəsizlik tədbirlərinin həyata keçirilməsi barədə məlumatlandırmaqla onların gizliliyini mühafizə etmolidir.

- Gizlilik qanunları, siyasəti və standartları VE tətbiqlərini işləyib hazırlayanları daha yaxşı təcrübələrə doğru təlimatlandırmaq üçün mövcuddur.

$\mathrm{Bu}$ misallar vasitəsilə VE-də iştirakçıların gizliliyini mühafizə edən hüquqi və siyasət mülahizələrini araşdırmaq mümkündür. Ümumiyyətlə, layihələr hüquq və etik standartları təşkilati təcrübələrlə əlaqələndirən siyasəti inkişaf etdirə bilər. $\mathrm{Bu}$ siyasət istifadəçilərə məlumatlı qərarlar qəbul etməyə imkan yaratmaqla gizliliyi dəstəkləyir. Digər hallarda, həllər istifadəçiləri mühafizə edən avtomatlaşdırılmış proseslərlə birlikdə texnologiyalara çevrilir.

Uşaqların Onlayn Gizliliyinin Qorunması Qanunu (Children's Online Privacy Protection Act - COPPA) 13 yaşdan aşağı hər kəsin şəxsi informasiyasının toplanılmasını məhdudlaşdırır [5]. Bu qanun Project BudBurst (www.budburst.org) və iNaturalist (www.inaturalist.org) də daxil olmaqla bir çox VE layihələrinə tətbiq olunur. COPPA-ya əsasən, veb-saytın ana səhifəsi və şəxsi informasiyanın toplanıldığı hər bir səhifə hansı verilənlərin və necə toplanılmas1, bu verilənlərin necə istifadə olunması, verilənlərə məsuliyyət daşıyan şəxslə əlaqə informasiyası, yetkinlik yaşına çatmayanların valideyn hüquqlarını izah edən verilənlər siyasətinə keçid (link) qeyd olunmalıdır. Project BudBurst layihəsi "Verilənlər siyasəti" səhifəsinə keçid təmin etməklə COPPA ilə uyğunlaşır. Olavə olaraq, Project BudBurst layihəsinə qoşulan könüllülərdən "Mənim ən azı 13 yaşım var" düyməsini basmaq tələb olunur. Könüllülərə məlumat verilir ki, "ogər sizin yaşınız 13-dən azdırsa, o zaman yerinizə valideyniniz və ya müəlliminiz qeydiyyatdan keçsin". Bu düymə basılmadıqda qeydiyyat təsdiqlənmir. Beləliklə, Project BudBurst layihəsi COPPA-ya uyğunlaşmaq üçün həm siyasət, həm də texnoloji həlləri təmin edir.

Layihələrdə iştirak edən vətəndaşlar şəxsi mesajlar vasitəsilə də əlaqə saxlaya bilir. Bəzi layihələr çərçivəsində, məsələn, iNaturalist-də şəxsi mesajların məzmununa nəzarət olunmas1 mümkün olmur. Ona görə də bu cür layihələr iştirakçılara əvvəlcədən yaş məhdudiyyəti qoyur.

VE layihələrinin həyata keçirilməsi üçün onlayn alətlər və resurslar təmin edən Citsci.org portalına nəzər salaq. Saytın Features bölməsində "Make your data public or keep it private" başlığının olması burada hər bir layihə yaradıldığı zaman gizliliyin seçilməsinə imkan verir. Bəzi hallarda açıq yaradılan VE layihəsində toplanılan müəyyən məlumatları gizli saxlamaq lazım gəlir. $\mathrm{Bu}$ halda verilənlər üçün gizliliyin tənzimləməsi həyata keçirilir. Portalda hazırda bu funksiya bir qədər məhduddur: ya bütün verilənlər gizli, ya da hamısı açıq ola bilir, lakin gələcəkdə yalnız seçilən verilənlərin gizli və ya açıq 


\section{“Informasiya tohlükosizliyinin aktual multidissiplinar elmi-praktiki problemlori” IV respublika konfransı, 14 dekabr 2018-ci il}

paylaşılmasını mümkün edən daha geniş seçimlər üzərində işlər aparilır.

Digər problemlər VE müşahidələri haqqında sənədləşdirilməli olan informasiyanın gizliliyi, təhlükəsizliyi və buna aid icazələrlə bağlıdır [6]. Layihə koordinatorları və könüllü iştirakçılar kimin nəyi, harada və nə zaman məlumat verməsi aspektlərindən hansılarının paylaşıla biləcəyi, hansılarının isə gizli saxlanılmalı olduğu barədə qərar verməyi bacarmalıdırlar. Koordinatorlar elmdə uyğun sənədləşdirmənin vacibliyini tanımaqla verilənləri təqdim edən könüllülərin təhlükəsizlik barədə narahatlıqlarını başa düşməli və buna hörmətlə yanaşmalıdırlar. Məsələn, bəzi hallarda verilənləri toplayan şəxs anonim qalmaq, digər bir vəziyyətdə isə $\mathrm{o}$, müəllifliyin bildirilməsini istəyə bilər. Narahatlıq doğuran ərazilərdə toplanılmış verilənlər bəzən gizli saxlanılmalı olur $\mathrm{ki}$, dəqiq ərazilər tanına bilməsin. Bu isə informasiya və verilənlərin idarə olunması ilə bağlı problemlər yaradır, bu cür problemlər isə yalnız layihə koordinatorları ilə əlaqə saxlamaqla və birgə layihələndirmə imkanları vasitəsilə həll oluna bilər. Layihə koordinatorları könüllülərin gizliliyini qorumaq məqsədilə bir sira mexanizmlərdən, o cümlədən texnoloji mühafizə və verilənlər siyasətlərindən istifadə edirlər. Geniş istifadə olunan bir metod məkanın qeyri-səlisləşdirilməsi və ya gizlədilməsidir [7]. Bəzi sistemlərdə qeyri-səlis verilənlər olur, bu isə o deməkdir ki, dəqiq məkan qeyri-müəyyən edilir. Bunu layihə koordinatoru edir, ona görə də məkanı bircə o özü görür. $\mathrm{Bu}$ metoddan landşaftın gizlədilməsi üçün istifadə olunsa da, insanlar da ondan öz yaşayış yerlərinin gizlədilməsi məqsədilə xeyli yararlana bilər. Gizliliyin digər qorunması üsulu toplanılan və paylaşılan şəxsi informasiyanın həcminin məhdudlaşdırılmasıdır. Elmi cəhətdən verilənləri kimin təqdim etdiyinin məlum olması vacib olduğu üçün, əksər layihələr könüllünün adını onun təqdim etdiyi verilənlərlə əlaqələndirir. $\mathrm{Bu}$ cür informasiyanın göstərilməsi barədə seçimdən asılı olaraq layihə koordinatorları könüllülərə hər iki seçimi anonim identifikasiya və ya öz istifadəçi adlarını yaratmağ təklif edirlər [8].

\section{VӘTəNDAŞ ELMINDӘ TəHLÜKəSIZLIK TəDBİRLəRI}

İT-nin tətbiqi ilə əlaqədar meydana çıxan problemlərin VEdə elmi-metodoloji prinsiplərə əsaslanan informasiya təhlükəsizliyinin təmin edilməsini, həmçinin şəbəkə texnologiyalarının müasir inkişaf meyllərinin nəzərdə tutulduğu hüquqi, təşkilati, texniki və fiziki mühafizə tədbirlərini qarşılıqlı surətdə əlaqələndirməklə informasiya təhlükəsizliyi siyasətinin yaradılmasını zəruri edir. İnformasiya təhlükəsizliyinin təmin edilməsi dedikdə informasiyanın konfidensiallığının, tamlığının vo əlyetənliyinin təmin edilməsi başa düşülür. İnformasiyanın konfidensiallığı informasiyaya çıxış yalnız icazə verilmiş şəxslərə verildiyi, tamlı̆̆ verilənlərə razılaşdırılmış dəyişikliklər edildikdə, əlyetənliyi isə icazə verilmiş şəxslərin lazımi vaxtda informasiya resurslarına çıxış əldə etdikləri halda təmin edilir. VE-də bu məsələlərlə bərabər toplanan böyük həcmli verilənlərin verifikasiyası da mühüm əhəmiyyət daşıyır.

Vətəndaşların şəxsi həyatı, virtual məkanda və layihələrdə fəaliyyəti haqqında fərdi məlumatların qorunması mühüm əhəmiyyət kəsb edir. VE layihələri həyata keçirilən zaman onun vətəndaş iştirakçılarına məxsus böyük həcmdə fərdi məlumatlar toplanır. Fərdi məlumatların toplanması, emalı və saxlanması məsələlərin səmərəli həlli VE-nin təhlükəsizliyi üçün vacib məsələlərdəndir. Fərdi məlumat dedikdə şəxsin kimliyini birbaşa və ya dolayı yolla müəyyənləşdirməyə imkan verən istənilən məlumat nəzərdə tutulur.

Avropa İnsan Hüquqları Konvensiyasının (European Convention on Human Rights) 8-ci maddəsində göstərilir ki, fərdi məlumatlar vətəndaşın hüquqlarının ayrılmaz hissəsini təşkil edir, vətəndaşın şəxsi həyatına və yazışma sirrinə hörmət edilmolidir.

Birləşmiş Ştatlarda vətəndaşların, o cümlədən VE ilə məşğul olanların gizliliyini qoruyan federal qanunlar var. Bunlara əsasən VE layihələri şəxsi informasiyanı toplamayan və ya şəxslərin məlumatları əsasında axtarıla bilinməyən verilənlər bazası yaratmağı seçə bilərlər. Ogər onlar şəxsi informasiyanı toplayarsa, bunu istifadəçinin hüquqları barədə informasiyanı təmin etməklə qəbul olunmuş aktlar ilə uyğunlaşdırmalıdır. Bu aktlar layihələrin verilənlər topluları ictimaiyyətə açıq paylaşılmazdan əvvəl onlardan şəxsi informasiya silinməsini müəyyənləşdiri.

Elm və Texnologiya Siyasəti Ofisi (Office of Science and Technology Policy - OSTP) (www.whitehouse.gov/ostp/) tərəfindən təsdiqlənmiş memorandumlar Birləşmiş Ştatların bu sahədə əlavə resurslarıdır. Məsələn, "Federal Maliyyələşdirilmiş Tədqiqatın Nəticələrinə İctimai Girişin Genişləndirilməsi” adlandırılmış bir memorandum agentliklərə konfidensiallıq və şəxsi gizliliyi qorumaqla bərabər nəşr edilmiş verilənlərə giriş hüququnu genişləndirməyi təklif edir. Birləşmiş Ştatlardan kənardak1 standartlara İqtisadi Kooperasiya (Oməkdaşlıq) və İnkişaf Təşkilatı (Organization for Economic Cooperation and Development - OECD) tərəfindən təsdiq edilmiş prinsiplər daxildir [9]. Avropa Birliyi standartları ümumilikdə Birləşmiş Ştatların standartlarından daha ciddidir.

AR-in 11 may 2010-cu il, 998-IIIQ sayl1 "Fordi məlumatlar haqqında" Qanunun 8-ci maddəsində deyilir: "Azərbaycan Respublikasının qanunvericiliyi ilə müəyyən olunmuş qaydada fərdi məlumatların məcburi şəkildə toplanılması və işlənilməsi halları istisna olmaqla, hər hansı şəxs barəsində fərdi məlumatların toplanılmasına və işlənilməsinə yalnız subyekt tərəfindən verilmiş yazıl1, o cümlədən gücləndirilmiş elektron imzalı elektron sənəd formasında razılıq və ya özünün yazılı təqdim etdiyi molumatlar əsasında yol verilir". Fərdi məlumatların toplanılması, emalı və ötürülməsi yalnız "Fərdi məlumatlar haqqunda" Qanuna uyğun olaraq həyata keçirilə bilər.

ARKonstitusiyasının 50-ci maddəsinə uyğun olaraq hər kəsin istədiyi informasiyanı qanuni yolla axtarmaq, əldə etmək, ötürmək, hazırlamaq və yaymaq azadlığı vardır. Eyni zamanda, informasiya azadlığının həyata keçirilməsi digər insanların hüquqlarının, azadlıqlarının və qanuni maraqlarının pozulmasina səbəb olmamalidir.

E-elmdə mövcud olan təhlükəsizlik problemləri və təhdidlər VE-də də mövcuddur [2]. VE layihələrinin təhlükəsizlik məsələləri: 
- texniki qurğular və avadanlıqlar, proqram vasitələri üçün təhlükəsiz konfiqurasiyaların seçilməsi,

- təhlükəsizliyə aid proqram vasitələrinin tətbiqi,

- səlahiyyətli və icazəsiz qurğuların və proqram vasitələrinin inventarlaşdırılması,

- müdafiə sərhədinin seçilməsidir.

E-elmə analoji olaraq, VE-də də təhlükəsizliyə nəzarət və mühafizə məsələləri aşağıdakılardır:

- $\quad$ səlahiyyətə uyğun girişə nəzarət;

- naqilsiz girişə nəzarət;

- zərərli proqramlardan mühafizə;

- verilənlərin qorunmasi, onların bərpa edilməsi imkanlarının nəzərə alınması.

VE-nin mühafizəsinin səmərəli təşkili və həyata keçirilməsinə xidmət edən göstərilmiş məsələlərin həlli zamanı aşağıdakılar nəzərə alınmalıdır:

- baş vermiş təhdidlərin öyrənilməsi və qarşısının alınması nəticəsində əldə olunmuş biliklər əsasında praktiki mühafizənin qurulması;

- $\quad$ prioritetin ən təhlükəli təhdidlərdən mühafizəni təmin edəcək tədbirlərə verilməsi;

- lazımi düzəlişlərin təyin edilməsi və tez həyata keçirilə bilməsi üçün təhlükəsizlik tədbirlərinin səmərəliliyinin qiymətləndirilməsinin ümumi göstəricilərinin olması;

- mövcud təhlükəsizlik tədbirlərinin səmərəliliyini yoxlamaq üçün fasiləsiz diaqnostikanın həyata keçirilməsi və mühafizənin maksimal dərəcədə avtomatlaşdırılması.

VE layihələrinin və digər kraudsorsing təşəbbüslərinin rəhbərləri təhlükəsizliyi təmin etmək üçün bir sıra təhlükəsizlik siyasətləri hazırlaya bilər. Bu məsələdə aşağıdakı təcrübələrdən istifadə etmək əlverişli olar [5]:

- Tamlıq, ictimai əlyetənlik və verilənlərin paylaşılması nöqteyi-nəzərdən verilənlərin seçilməsi, bu seçimlərin təsdiq olunması və onları dəstəkləyən texnologiyaların həyata keçirilməsi;

- Konfidensiallığın seçilməsi ilə bağlı geniş imkanların verilməsi, normal iştirakın hansı hallarda şəxsi gizliliyə risk olmasının izahı, könüllülərin bu barədə xəbərdar edilməsi;

- Könüllülərə müəyyən verilənləri ictimaiyyətdən gizlədilməsi və ya gizlədilməməsi hallarında anonimliyi təmin etmək üçün seçim verilməsi;

- Könüllülərə verilənləri silmək və dəyişdirmək imkanı yaradilması;

- Könüllülər haqqında minimal informasiya tələb edilməsi.

VE layihələrinin veb-səhifələrinə giriş zamanı biometrik identifikasiya metodlarından istifadə edilməsi təhlükəsizliyin təmin edilməsi üçün görülə biləcək ən qabaqcıl tədbirlərdən biridir. $\mathrm{Bu}$, veb-səhifəyə daxil olan şəxslərin özləri haqqında düzgün məlumat daxil etməsini təmin edəcək.

\section{NəTісə}

Araşdırmalar göstərir ki, İT-nin son nailiyyətlərinin tətbiqi ilə VE intensiv olaraq inkişaf edir. Bununla yanaşı onun təhlükəsizliyinin təmin olunması mürəkkəb bir məsələ kimi aktuallaşır. İnformasiya təhlükəsizliyinin konfidensiallıq, tamlıq və əlyetənliyin təmin edilməsi və fərdi məlumatların qorunması kimi məsələləri tədqiq olunaraq vətəndaş elminin effektiv mühafizəsi üçün prioritet istiqamətlər göstərilmişdir. İnormasiya təhlükəsizliyi üzrə təqdim olunmuş bu konseptual yanaşmanın tətbiqi ilə VE-nin inkişafında mühüm nəticələr əldə oluna bilər.

\section{ӘDӘBIYYAT}

[1] R.M. Alguliyev, R.G. Alakbarov, T.Kh.Fataliyev, Electronic science: current status, problems and perspectives", Problems of information technology, №2, 2015, pp. 4-14, DOI: 10.25045/jpit.v06.i2.01

[2] T.Kh.Fataliyev, "Security provision issues of e-science, Problems of information society”, №1, 2016, pp. 50-55, DOI: 10.25045/jpis.v07.i1.06

[3] European Citizen Science Association, www.ecsa.citizen-science.net

[4] J.P. Cohn, Citizen science: Can volunteers do real research?, BioScience , Vol. 58, No. 3, 2008, pp. 192-197.

[5] A. Bowser and o., "Sharing data while protecting privacy in citizen science”, İnteractions, Vol. 21, Issue 1, 2014, pp. 70-73.

[6] T. Scassa, H. Chung. "Typology of citizen science projects from an intellectual property perspective", Wilson center-Commons Lab, 2015, www.wilsoncenter.org/sites/default/files/Typology_of_Citizen_Science_ IP_Rights_Scassa.pdf

[7] B. Sullivan, et al., "The eBird enterprise: An integrated approach to development and application of citizen science", Biological Conservation 169, 2014, pp.31-40.

[8] A. Bowser, K. Shilton, J. Preece, E. Warrick. "Accounting for Privacy in Citizen Science: Ethical Research in a Context of Openness", 2017, https://terpconnect.umd.edu/ kshilton/pdf/BowserEtAlCSCW.pdf

[9] OECD Guidelines on the Protection of Privacy and Transborder ..., www.oecd.org/internet/ieconomy/oecdguidelinesontheprotectionofpriva cyandtransborderflowsofpersonaldata.htm

\section{ABOUT INFORMATION SECURITY OF CITIZEN SCIENCE \\ Tahmasib Fataliyev ${ }^{1}$, Nargiz Verdiyeva ${ }^{2}$ \\ ${ }^{1,2}$ Institute of Information Technology of ANAS, Baku, Azerbaijan depart3@iit.science.az}

Abstract - Citizen science, characterized by the participation of a large number of volunteers in large-scale spatial and time-scale quantitative measurements and observations, is rapidly developing with the application of information technologies. The article is dedicated to the research of information security issues to ensure its efficient performance. Issues such as confidentiality, completeness, accessibility and protection of personal data are studied and priority directions for effective protection of citizen science are shown.

Keywords - e-science; citizen science; open science; information security; citizen science projects. 